\title{
KOMBINASI PAKAN KOMERSIL DENGAN CACING DARAH (Chironomus sp) TERHADAP PERTUMBUHAN, DAN KELANGSUNGAN HIDUP IKAN MAS KOKI (Carrassius auratus)
}

\author{
Combination Commercial Feed with Bloodworm (Chironomus sp) against Growth, \\ and Survival Of Goldfish (Carrassius auratus)
}

\author{
Herman Suhendri $^{1}$, Helmi Harris ${ }^{2}$, dan Rih Laksmi Utpalasari ${ }^{2}$ \\ 1) Alumni Fakultas Perikanan Universitas PGRI Palembang \\ 2) Staf Pengajar Fakultas Perikanan Universitas PGRI Palembang \\ Email : perikanan.pgri@gmail.com
}

\begin{abstract}
Abstrak
Penelitian telah dilaksanakan pada bulan Mei 2017 sampai dengan Juni 2017 di Kampus C Fakultas Perikanan Universitas PGRI Palembang, Kecamatan Sematang Borang Palembang. Tujuan penelitian ini untuk mengetahui mengetahui pertambahan pertumbuhan dan kelangsungan hidup Ikan Mas Koki. Metode yang digunakan adalah metode eksperimen dengan menggunakan rancangan acak lengkap (RAL) dengan 4 perlakuan yang masing masing perlakuan dilakukan 3 kali ulangan. P0 : Tanpa Cacing Darah (kontrol), P1 : Pemberian tepung Cacing Darah 25\% pada pakan pellet 75\%, P2 : Pemberian tepung Cacing Darah 50\% pada pakan pellet 50\%, dan P3 : Pemberian tepung Cacing Darah 75\% pada pakan pellet 25\%. Hasil penelitian menunjukkan bahwa pertambahan berat Ikan Mas Koki (Carrassius auratus) tertinggi terletak pada perlakuan P2 yaitu pemberian tepung Cacing Darah 50\% pada pakan pellet 50\% dengan rata-rata pertambahan berat sebesar 0.694 gram, sedangkan pertambahan panjang Ikan Mas Koki (Carrassius auratus) tertinggi terletak pada perlakuan P3 yaitu pemberian tepung Cacing Darah 75\% pada pakan pellet $25 \%$ dengan rata-rata pertambahan panjang sebesar $0.96 \mathrm{~cm}$. Kelangsungan hidup Ikan Mas Koki (Carrassius auratus) tertinggi terletak pada perlakuan P3 yaitu pemberian tepung Cacing Darah $75 \%$ pada pakan pellet $25 \%$ dengan rata-rata persentase sebesar $83,33 \%$.
\end{abstract}

Kata Kunci : Cacing Darah (Chironomus sp), Pertumbuhan, dan Kelangsungan Hidup.

\begin{abstract}
The research was conducted in May 2017 until June 2017 at Campus C Faculty of Fishery University PGRI Palembang, District of Sematang Borang Palembang. The purpose of this research is to know growth and survival rate carp (Carrassius auratus. The method used was experimental method by using complete randomized design (RAL) with 4 treatment which each treatment was done 3 times replication. P0: No blood glucose (control) P1: Blood meal flour 25\% in pellet feed 75\%, P2: Flouring 50\% bloodworm on 50\% pellet feed, and P3: Flouring 75\% blood glucose on pellet feed $25 \%$. The result of the research showed that the highest concentration of Fish Mas Koki (Carrassius auratus) was the treatment of $P 2$, which was $50 \%$ of the blood worm feeding on 50\% pellet feed with average weight gain of 0.694 gram, while the length of the Fish Mas Koki (Carrassius auratus) highest lies in the treatment of $P 3$ that is the feeding of $75 \%$ blood worm feed on $25 \%$ pellet feed with average length increase of 0.96 $\mathrm{cm}$. The survival of the Goldfish (Carrassius auratus) is highest in P3 treatment which is $75 \%$ blood meal worm feeding on $25 \%$ pellet feed with average percentage of $83.33 \%$.
\end{abstract}

Keywords: Goldfish (Carrassius auratus), Growth, and Survival Rate 


\section{PENDAHULUAN}

Perkembangan produksi budidaya ikan hias Indonesia selama tahun 2009-2012 cenderung meningkat dari sebesar 566 juta ekor pada 2009 menjadi 978 juta ekor pada 2012 atau mengalami peningkatan rata-rata sebesar $18,9 \%$ per tahun. Dari data Kementerian Kelautan dan Perikanan sampai dengan tahun 2011 Indonesia baru menguasai $6,95 \%$ perdagangan ikan hias dunia atau menduduki ranking ke-5 setelah Republik Ceko, Thailand, Jepang dan Singapura (Darmawan, 2014).

Indonesia memiliki perairan tawar yang sangat luas dan berpotensi besar untuk usaha berbagai macan jenis ikan air tawar. Ikan hias air tawar merupakan salah satu alternatif usaha untuk menjalankan perekonomian yang banyak menghasilkan devisa. Menurut Gustiano (2014), Sumatera Selatan khususnya di Kota Palembang menghasilkan 29.160 ton ikan hias. Ikan hias tersebut, berasal dari daerah aliran Sungai Musi maupun hasil budidaya. Khusus pada ikan mas koki, penjual membeli benih di Sukami Jawa Barat. Pemasaran ikan mas koki ini masih memenuhi kawasan pasar kota Palembang. Ikan mas koki digemari konsumen dengan alasan warna yang menarik, semakin menarik dan cerah warna ikan maka harga ikan akan semakin tinggi.

Salah satu ikan hias yang cukup terkenal di kalangan penggemar ikan adalah Ikan Mas Koki (Carrassius auratus) (Yusuf, 2009). Kandungan protein cacing tersebut mencapai $60 \%$ yang mudah dicerna oleh ikan. Cacing tersebut juga telah digunakan sebagai pakan udang windu dan udang galah (Parlinggoman dan Sumantadinata, 2007). Larva Chironomus banyak terdapat diperairan yang mengandung bahan organik tinggi. Kandungan protein yang tinggi akan menyebabkan ikan yang mengkonsumsinya menjadi lebih sehat sehingga ikan tersebut warnanya menjadi lebih cerah (Widanarni et al, 2006). Adapun tujuan dari penelitian ini adalah : 1). Untuk mengetahui pertambahan berat dan panjang Ikan Mas Koki (Carrassius auratus) dengan penambahan tepung Cacing Darah (Chironomus sp) pada pakan dan 2). Untuk mengetahui kelangsungan hidup Ikan Mas Koki (Carrassius auratus) dengan penambahan tepung Cacing Darah (Chironomus sp) pada pakan.

\section{METODE PENELITIAN}

Penelitian ini dilaksanakan pada bulan Mei - Juni 2017 dilaksanakan di Kampus C Fakultas Perikanan Universitas PGRI
Palembang. Jalan Sakti Wiranata Kelurahan Srimulia Kecamatan Sematang Borang Palembang. Metode penelitian yang digunakan dalam penelitian ini adalah Rancangan Acak Lengkap (RAL) dengan 4 taraf perlakuan dan 3 kali ulangan Tiap perlakuan akan diberikan pakan komersil dengan penambahan Cacing Darah sebanyak 25\%, 50\%,dan $75 \%$. Adapun perlakuan dalam penelitian ini adalah sebagai berikut :

P0 : Tanpa Cacing Darah (pelet 100\%)

P1 : Pemberian tepung Cacing Darah 25\%, pakan pellet $75 \%$

P2 : Pemberian tepung Cacing Darah 50\%, pakan pellet $50 \%$

P3 : Pemberian tepung Cacing Darah 75\%, pakan pellet $25 \%$

Pengamatan yang dilakukan meliputi :

\section{Pertambahan Berat}

Pengukuran berat tubuh Ikan Mas Koki dilakukan sebelum dan sesudah pemeliharaan menggunakan timbangan digital kemudian dihitung berdasarkan rumus Effendie (1997) :

$$
\mathbf{W m}=\mathbf{W t}-\mathbf{W o}
$$

Keterangan :

Wm : Pertambahan berat rata - rata $(\mathrm{g})$

$\mathrm{Wt}$ : Berat rerata ikan akhir penelitian $(\mathrm{g})$

Wo : Berat rerata ikan awal penelitian $(\mathrm{g})$

\section{Pertumbuhan Panjang}

Pengukuran panjang pada Ikan Mas Koki (Carrassius auratus) dilakukan sebelum dan sesudah pemeliharaan menggunakan penggaris. Pertumbuhan panjang menurut Effendie (1997) diukur menggunakan rumus :

$$
\mathbf{P m}=\mathbf{P t}-\mathbf{P o}
$$

Keterangan :

$\mathrm{Pm}=$ Pertumbuhan panjang rata - rata $(\mathrm{cm})$

Pt = Panjang rerata ikan akhir penelitian $(\mathrm{cm})$

Po = Panjang rerata ikan awal penelitian $(\mathrm{cm})$

\section{Kelangsungan Hidup}

Menurut Effendie (1997) dihitung menggunakan rumus, yaitu;

$$
S R=\frac{N t}{N o} \times 100 \%
$$

Keterangan :

$\mathrm{SR}=$ Survival Rate $(\%)$

$\mathrm{Nt}=$ Jumlah ikan pada akhir penelitian (ekor) No $=$ Jumlah ikan pada awal penelitian (ekor)

Parameter kualitas air yang diamati adalah suhu, $\mathrm{pH}$, oksigen terlarut (DO) dan ammonia. Analisa data yang dilakukan dalam penelitian ini menggunakan Rancangan Acak Lengkap (RAL). Pengaruh perlakuan ditentukan dengan analisa sidik ragam. Jika dari analisa sidik ragam diketahui bahwa perlakuan strain yang berbeda menunjukkan pengaruh yang berbeda nyata atau sangat nyata akan diuji 
lanjut apabila Fhitung $>$ Ftabel dan data kualitas air diuji secara deskriptif (Hanafiah 2011).

\section{HASIL DAN PEMBAHASAN}

\section{Pertambahan Berat Ikan Mas Koki (Carassius auratus)}

Pengamatan hasil penelitian penambahan konsentrasi tepung Cacing Darah pada pakan terhadap pertambahan berat rata-rata Ikan Mas Koki (Carassius auratus). Data rata-rata pertambahan berat Ikan Mas Koki selama penelitian dapat dilihat pada Tabel 1 dan

Tabel 1.Pertambahan Berat Rata-Rata (gram)

Ikan Mas Koki (Carassius auratus)

\begin{tabular}{|c|c|c|c|c|c|}
\hline \multirow[t]{2}{*}{ Perlakuan } & \multicolumn{3}{|c|}{ Ulangan } & \multirow{2}{*}{$\begin{array}{c}\text { Jumlah } \\
\text { (gr) }\end{array}$} & \multirow{2}{*}{$\begin{array}{c}\text { Rerata } \\
\text { (gr) }\end{array}$} \\
\hline & 1 & 2 & 3 & & \\
\hline P0 & 0.258 & 0.24 & 0.192 & 0.690 & 0.230 \\
\hline $\mathrm{P} 1$ & 0.266 & 0.682 & 0.39 & 1.338 & 0.446 \\
\hline $\mathrm{P} 2$ & 0.806 & 0.682 & 0.594 & 2.082 & 0.694 \\
\hline P3 & 0.5 & 0.24 & 0.204 & 0.944 & 0.315 \\
\hline
\end{tabular}

Berdasarkan tabel 1 di atas, dapat disimpulkan bahwa seluruh perlakuan baik pada perlakuan $\mathrm{P}_{0}$ hingga perlakuan $\mathrm{P}_{3}$ berat Ikan Mas Koki mengalami pertambahan berat ratarata Ikan Mas Koki pada perlakuan P0 sebesar 0,69 gram, sedangkan pada perlakuan P1 sebesar 1,338 gram, Pada perlakuan P2 sebesar 2,082 gram, sedangkan pada perlakuan P3 sebesar 0.944 gram. Hal ini kemungkinan dipengaruhi dengan pemberian pakan pelet yang

Tabel 2.Pertambahan Berat Rerata (cm) Ikan Mas Koki (Carassius auratus)

\begin{tabular}{ccccccc}
\hline SK & DB & JK & KT & $\mathbf{F}_{\text {hitung }}$ & $\mathbf{F}_{\text {tabel }(\mathbf{0}, \mathbf{0 5})}$ & $\mathbf{F}_{\text {tabel }(\mathbf{0 , 0 1})}$ \\
\hline Perlakuan & 3 & 0.8995 & 0.2998 & $5.8398^{*}$ & 4.07 & 7.59 \\
Galat & 8 & 2.2576 & 0.2822 & - & & \\
\hline Total & $\mathbf{1 1}$ & $\mathbf{3 . 1 5 7 1 0 7 7}$ & - & & & \\
\hline
\end{tabular}

Keterangan: * : berpengaruh nyata

$\mathrm{KK}=5,81 \%$

Pada tabel 2, data hasil analisis sidik ragam menunjukkan bahwa penambahan konsentrasi tepung Cacing Darah pada pakan terhadap pertambahan berat Ikan Mas Koki (Carassius auratus) didapat $\mathrm{F}_{\text {hitung }}>\mathrm{F}_{\text {tabel }}$ pada taraf signifikan 5\% menunjukkan hasil berpengaruh nyata antar taraf perlakuan.

Tabel 3. Uji BNT (Beda Nyata Terkecil) Berat Mas Koki (Carassius auratus)

\begin{tabular}{|c|c|c|c|c|c|}
\hline \multirow[t]{2}{*}{ Perlakuan } & \multirow[t]{2}{*}{ Rerata } & \multicolumn{4}{|c|}{ Beda Rata-rata } \\
\hline & & $\mathbf{P 0}$ & P1 & P2 & P3 \\
\hline P3 & 0.315 & $0.085^{\mathrm{tn}}$ & $0.131^{\mathrm{tn}}$ & $0.379^{* * *}$ & - \\
\hline $\mathrm{P} 2$ & 0.694 & $0.464^{* *}$ & $0.248^{*}$ & - & \\
\hline P1 & 0.446 & $0.216^{\mathrm{tn}}$ & - & & \\
\hline $\mathrm{P} 0$ & 0.230 & - & & & \\
\hline \multicolumn{2}{|c|}{ BNT $(0,05)=0.220$} & \multicolumn{3}{|c|}{ BNT $(0,01)=0.343$} & \\
\hline \multicolumn{6}{|c|}{$\begin{array}{l}\text { Ket: } \\
* * \text { Berbeda sangat nyata }\end{array}$} \\
\hline
\end{tabular}

di campuran Cacing Darah sebanyak 50\% membuat tingkat pertambahan berat Ikan Mas Koki lebih baik. Pertambahan berat Ikan Mas Koki menunjukkan bahwa pertambahan berat Ikan Mas Koki secara umum yaitu pada akhir pengamatan. Pertambahan berat Ikan Mas Koki dari hari pertama sampai kehari hari 30 mulai semakin terlihat peningkatan secara signifikan dari masing-masing perlakuan.

Adapun pertambahan berat rata-rata (gram) Ikan Mas Koki (Carassius auratus) pada berbagai perlakuan selama penelitian dapat dilihat pada Gambar 1 di bawah ini.

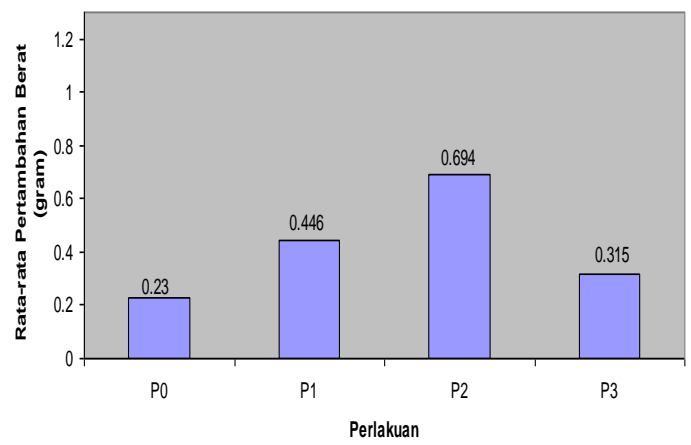

Gambar 1. Pertambahan Berat Rerata Ikan Mas Koki (Carassius auratus)

Berdasarkan perhitungan analisis statistik pertambahan berat Ikan Mas Koki sidik ragam pertambahan berat ikan selama penelitian dapat dilihat pada Tabel 2 (Carassius auratus) diperoleh hasil analisis
Dengan demikian, uji perlakuan yang berbeda nyata ini karena selisih dari dosis antar perlakuan. Hasil data uji BNT penambahan konsentrasi tepung Cacing Darah pada pakan terhadap berat Ikan Mas Koki (Carassius auratus) dapat dilihat pada Tabel 3 
Berdasarkan tabel 3 di atas, dapat diketahui bahwa pada perlakuan P3 berbeda sangat nyata dengan perlakuan $\mathrm{P} 2$, tetapi tidak berbeda nyata dengan perlakuan P0 dan P1. Selain itu, perlakuan P2 berbeda sangat nyata dengan perlakuan $\mathrm{P} 0$ dan berbeda nyata dengan perlakuan $\mathrm{P} 1$, sedangkan perlakuan $\mathrm{P} 1$ tidak berbeda nyata dengan perlakuan $\mathrm{P} 0$.

Berdasarkan hasil pengamatan diperoleh perbedaan pertambahan berat Ikan Mas Koki (Carassius auratus) yang dapat dilihat pada Gambar 2.

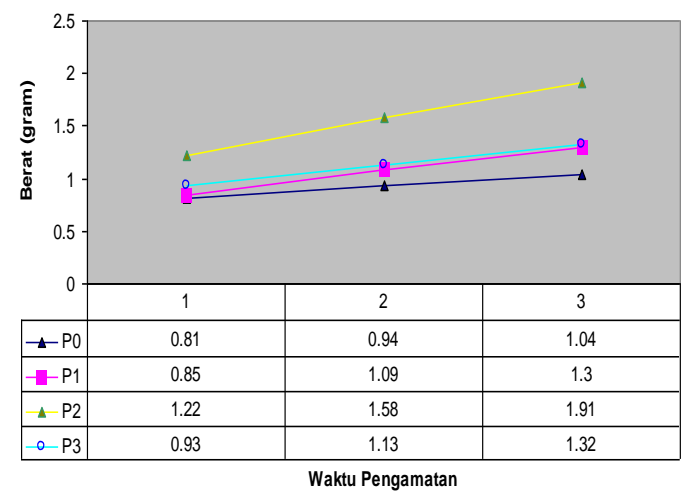

Gambar 2. Pertambahan Berat Ikan Mas Koki Selama Penelitian

Dari gambar 2 di atas, didapatkan ratarata pertambahan berat pada perlakuan P0 yaitu $1.04-0.81 / 30$ hari $=0.008$ gram $/$ hari. Selain itu, rata-rata pertambahan berat pada perlakuan $\mathrm{P} 1$ yaitu $1.3-0.85$ / 30 hari $=0.015$ gram $/$ hari, sedangkan pada perlakuan P2 rata-rata pertambahan berat yaitu $1.91-1.22$ / 30 hari $=$ 0.023 gram/hari. Pada perlakuan P3 didapatkan rata-rata pertambahan berat yaitu $1.32-0.93$ / 30 hari $=0.013$ gram $/$ hari. Berdasarkan grafik di atas diperoleh bahwa perlakuan P2 merupakan perlakuan dengan laju pertambahan berat yang terbaik dalam pemberian tepung Cacing Darah $50 \%$ pada pakan pellet $50 \%$ dengan pertambahan berat yaitu $0,023 \mathrm{gr} /$ hari. Menurut Khairuman dan Amri (2013), laju pertumbuhan ikan dipengaruhi oleh jenis dan kualitas pakan yang diberikan berkualitas baik, kesesuaian pencampuran pakan, jumlahnya mencukupi, kondisi lingkungan mendukung, dan dapat dipastikan laju pertumbuhan ikan akan menjadi cepat sesuai dangan yang diharapkan.

Secara uji ansira perlakuan penambahan tepung Cacing Darah pada pakan berpengaruh nyata pada pertambahan berat ikan. Secara biologis terlihat bahwa adanya perbedaan pertambahan berat masing-masing perlakuan. Hal ini diduga karena pemberian tepung Cacing Darah pada perlakuan P1, P2 dan P3 merangsang nafsu makan ikan sehingga adanya pertambahan berat ikan.
Hasil penelitian ini membuktikan bahwa pemberian pakan dengan Cacing Darah berpengaruh nyata terhadap pertambahan berat. Hal ini dikarenakan cacing memiliki kandungan protein dan karbohidrat yang tinggi. Selain itu, diduga karena dosis perlakukan P2 dengan pemberian tepung Cacing Darah $50 \%$ pada pakan pellet $50 \%$ sesuai dengan takaran yang disukai ikan. Dari hasil pengujian proksimat menyatakan bahwa kandungan protein dan karbohidrat yang terdapat pada perlakuan P2 masing-masing sebesar 38,58\% dan 33,27 gram.

Menurut Sunarto (2009), dalam usaha budidaya ikan, pakan merupakan salah satu faktor penting. Oleh sebab itu pakan harus berkualitas dengan kuantitas yang tepat sesuai dengan kebutuhan ikan untuk pertumbuhannya. Penelitian ini menghasilkan pertambahan berat lebih tinggi dibandingan penelitian Arief (2009) yang menyatakan bahwa kombinasi $50 \%$ pelet dan 50\% Cacing Darah memberikan pengaruh yang nyata terhadap berat ikan dengan rata-rata sebesar 0.5767 gram dan laju pertambahan berat sebesar 0,008200 gram/hari.

\section{Pertambahan Panjang Ikan Mas Koki (Carassius auratus)}

Berdasarkan hasil penelitian diperoleh rata-rata pertambahan panjang Ikan Mas Koki selama penelitian yang dapat dilihat Tabel 4

Tabel 4.Pertambahan Panjang Rata-Rata (cm)

Ikan Mas Koki (Carassius auratus) pada Berbagai Perlakuan Selama Penelitian

\begin{tabular}{|c|c|c|c|c|c|}
\hline \multirow[t]{2}{*}{ Perlakuan } & \multicolumn{3}{|c|}{ Ulangan (cm) } & \multirow{2}{*}{$\begin{array}{c}\text { Jumlah } \\
(\mathrm{cm})\end{array}$} & \multirow{2}{*}{$\begin{array}{c}\text { Rerata } \\
\text { (cm) }\end{array}$} \\
\hline & 1 & 2 & 3 & & \\
\hline $\mathrm{P} 0$ & 0.54 & 0.56 & 0.88 & 1.98 & 0.66 \\
\hline P1 & 0.96 & 0.72 & 0.82 & 2.5 & 0.833 \\
\hline P2 & 0.54 & 1.06 & 1 & 2.6 & 0.867 \\
\hline P3 & 0.7 & 0.84 & 1.34 & 2.88 & 0.96 \\
\hline
\end{tabular}

Berdasarkan tabel 4 di atas, pertambahan panjang rata - rata Ikan Mas Koki pada perlakuan P0 sebesar $0,66 \mathrm{~cm}$, sedangkan pada perlakuan $\mathrm{P} 1$ sebesar $0,833 \mathrm{~cm}$. pada perlakuan P2 sebesar $0,867 \mathrm{~cm}$ dan perlakuan P3 sebesar $0,96 \mathrm{~cm}$. Dari masing-masing perlakuan ratarata setiap perlakuan yang paling baik terjadi pada perlakuan P3 sebesar 0,96 cm. Hal ini kemungkinan dipengaruhi dengan pemberian pakan pelet yang di campuran Cacing Darah sebanyak $75 \%$ membuat tingkat pertambahan panjang Ikan Mas Koki lebih baik. Adapun ratarata pertambahan panjang Ikan Mas Koki dapat dilihat pada Gambar 3 berikut. 


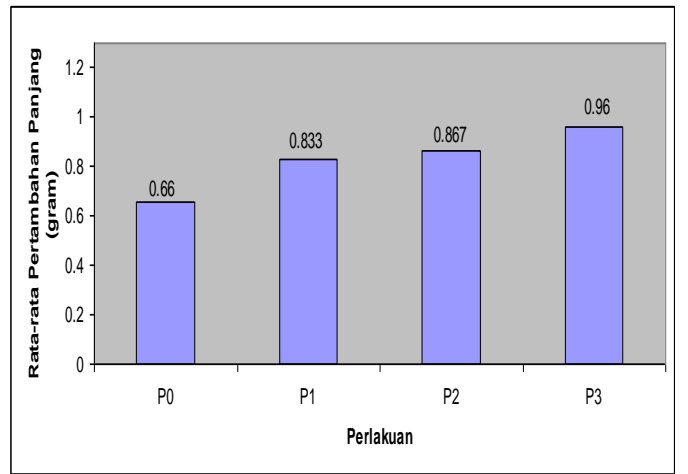

Gambar 3. Pertambahan Panjang Rata-Rata Ikan Mas Koki (Carassius auratus)

Pertambahan panjang pada Ikan Mas Koki terus mengalami peningkatan. Peningkatan yang tertinggi terjadi perlakuan P3

Tabel 5. Data Hasil Analisis Sidik Ragam Pertambahan Panjang Ikan Mas Koki (Carassius auratus) Selama Penelitian

\begin{tabular}{lcccccc}
\hline \multicolumn{1}{c}{ SK } & DB & JK & KT & F $_{\text {hitung }}$ & $\mathbf{F}_{\text {tabel }}(\mathbf{0 , 0 5})$ & $\mathbf{F}_{\text {tabel }}(\mathbf{0 , 0 1})$ \\
\hline Perlakuan & 3 & 0.1415 & 0.0472 & $0.7697^{\text {th }}$ & 4.07 & 7.59 \\
Galat & 8 & 0.4901 & 0.0613 & - & & \\
\hline Total & $\mathbf{1 1}$ & $\mathbf{0 . 6 3 1 6}$ & & & & \\
\hline
\end{tabular}

Keterangan: ${ }^{\text {tn }}$ berpengaruh tidak nyata

KK : $2,944 \%$

Pada tabel 5 di atas, data hasil analisis sidik ragam menunjukkan bahwa peningkatan rata-rata pertambahan panjang Ikan Mas Koki (Carassius auratus) didapat Fhitung < Ftabel pada taraf signifikan $5 \%$, sehingga dinyatakan berpengaruh tidak nyata antar perlakuan.

Pertambahan panjang Ikan Mas Koki (Carassius auratus) pada semua perlakuan bervariatif. Adapun perbedaan pertambahan panjang Ikan Mas Koki (Carassius auratus) dapat dilihat pada Gambar 4 berikut.

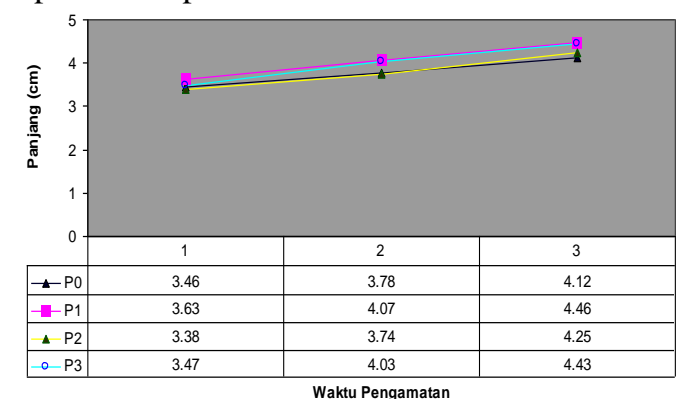

Gambar 4. Panjang Ikan Mas Koki Selama Penelitian

Berdasarkan gambar 4 di atas, diperoleh rata-rata laju pertambahan panjang Ikan Mas Koki pada perlakuan P0 yaitu 4.12-3.46 / 30 hari $=0.022 \mathrm{~cm} /$ hari, sedangkan pada perlakuan $\mathrm{P} 1$ rata-rata laju pertambahan panjang Ikan Mas Koki yaitu $4.46-3.63 / 30$ hari $=0.028 \mathrm{~cm} /$ hari. Selanjutnya, rata-rata laju pertambahan panjang Ikan Mas Koki pada perlakuan P2 yaitu 4.25 $3.38 / 30$ hari $=0.029 \mathrm{~cm} /$ hari, sedangkan rata- yaitu dengan pemberian tepung Cacing Darah $75 \%$ pada pakan pellet 25\%. Pertambahan panjang Ikan Mas Koki menunjukkan bahwa peningkatan panjang Ikan Mas Koki secara umum yaitu pada akhir pengamatan. Peningkatan panjang tubuh dari hari pertama sampai ke hari hari 30 mulai semakin terlihat peningkatan secara signifikan dari masingmasing perlakuan. Berdasarkan hasil pengamatan dapat dilihat bahwa seluruh pada perlakuan P0 hingga perlakuan P3 menunjukkan adanya pertambahan panjang ikan.

Berdasarkan perhitungan analisis statistik pertambahan panjang Ikan Mas Koki (Carassius auratus) diperoleh hasil analisis sidik ragam pertambahan panjang ikan selama penelitian dapat dilihat pada Tabel 5 rata laju pertambahan panjang pada perlakuan P3 yaitu $4.43-3.47$ / 30 hari $=0.032 \mathrm{~cm} /$ hari . Berdasarkan grafik di atas didapatkan bahwa perlakuan P3 menghasilkan laju pertambahan panjang yang terbaik dalam pemberian tepung Cacing Darah $75 \%$ pada pakan pellet $25 \%$ yaitu sebesar $0,032 \mathrm{~cm} /$ hari.

Hasil penelitian ini membuktikan bahwa penambahan tepung Cacing Darah (Chironomus sp) dengan konsentrasi yang berbeda berpengaruh tidak nyata terhadap pertambahan Panjang Ikan Mas Koki (Carrassius auratus). Menurut Effendie (2002) menyatakan bahwa pertambahan panjang ikan tidak secepat dengan pertambahan berat ikan. Selain itu, hasil penelitian Aggraeni dan Abdulgani (2013), pemberian pakan Cacing Darah berpengaruh tidak terhadap laju pertumbuhan panjang pada ikan dan mengalami peningkatan atau kenaikan selama penelitian.

Perbedaan ukuran berat dan panjang antara tiap ikan tersebut dapat dipengaruhi oleh berbagai faktor, seperti yang telah dikemukakan oleh Fujaya (1999), dimana ada dua faktor yang mempengaruhi pertumbuhan ikan yaitu faktor dalam dan faktor luar. Faktor dalam diantaranya adalah keturunan, jenis kelamin, umur, parasit dan penyakit. Sedangkan yang termasuk faktor luar adalah makanan dan kualitas perairan pada media pemeliharaan. 


\section{Kelangsungan Hidup}

Pengamatan hasil penelitian penambahan konsentrasi tepung Cacing Darah pada pakan terhadap kelangsungan hidup rata-rata Ikan Mas Koki (Carassius auratus) dapat dilihat pada Tabel 6

Tabel 6. Kelangsungan Hidup Rata-Rata (\%) Ikan Mas Koki (Carassius auratus) Selama Penelitian

\begin{tabular}{cccccc}
\hline Perlakuan & \multicolumn{3}{c}{ Ulangan } & Jumlah & Rerata \\
\cline { 2 - 4 } & $\mathbf{1}$ & $\mathbf{2}$ & $\mathbf{3}$ & & \\
\hline P0 & 70 & 60 & 70 & 200 & 66.67 \\
P1 & 70 & 70 & 80 & 220 & 73.33 \\
P2 & 90 & 70 & 80 & 240 & 80.00 \\
P3 & 90 & 80 & 80 & 250 & 83.33 \\
\hline
\end{tabular}

Berdasarkan data kelangsungan hidup rata-rata Ikan Mas Koki (Carassius auratus) pada Berbagai Perlakuan Selama Penelitian diperoleh bahwa seluruh perlakuan baik pada perlakuan $\mathrm{P}_{0}$ hingga perlakuan $\mathrm{P}_{3}$ mengalami peningkatan kelangsungan hidup ikan mas koki. Kelangsungan hidup rata-rata Ikan Mas Koki pada perlakuan P0 sebesar $66,67 \%$, sedangkan pada perlakuan P1 sebesar 73,33\%. Pada perlakuan P2 sebesar $80 \%$, sedangkan pada perlakuan P3 sebessar 83,33\%.

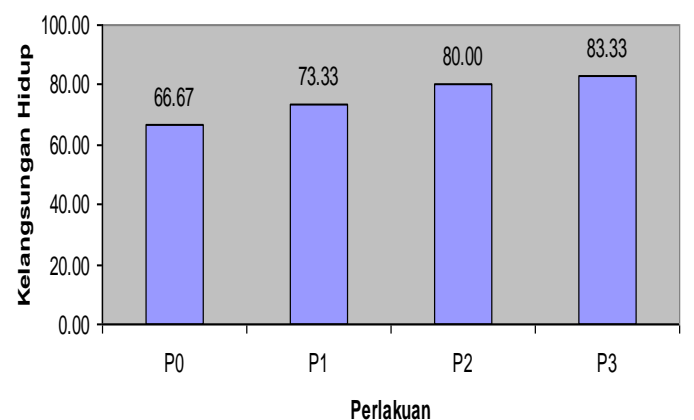

Gambar 5. Kelangsungan Hidup Ikan Mas Koki (Carassius auratus)

Tabel 7. Data Hasil Analisis Sidik Ragam Kelangsungan Hidup Ikan Mas Koki (Carassius auratus) Selama Penelitian

\begin{tabular}{lcccccc}
\hline \multicolumn{1}{c}{ SK } & DB & JK & KT & F $_{\text {hitung }}$ & $\mathbf{F}_{\text {Tabel }(\mathbf{0 , 0 5})}$ & $\mathbf{F}_{\text {Tabel }(\mathbf{0 , 0 1})}$ \\
\hline Perlakuan & 3 & 4.92 & 1.6389 & $3.2778^{\text {th }}$ & 4.07 & 7.59 \\
Galat & 8 & 4 & 0.5 & - & & \\
\hline Total & $\mathbf{1 1}$ & 8.92 & - & & \\
\hline Ket & & & & & \\
\end{tabular}

Keterangan: ${ }^{\text {tn }}$ berpengaruh tidak nyata

KK : $0,1 \%$

Pada tabel 7 di atas, data hasil analisis sidik ragam menunjukkan bahwa peningkatan rata-rata kelangsungan hidup Ikan Mas Koki (Carassius auratus) didapat Fhitung < FTabel pada taraf signifikan 5\%, sehingga dinyatakan berpengaruh tidak nyata antar perlakuan. Diduga karena selisih dari dosis antar perlakuan yang memberikan kelangsungan hidup ikan yang sama, artinya semua ikan dengan pemberian pakan yang berbeda baik pada
Berdasarkan hasil pengamatan ditemukan jumlah ikan yang mati selama penelitian. Adapun jumlah Ikan Mas Koki (Carassius auratus) yang mati selama pengamatan dapat dilihat pada Gambar 6 berikut.

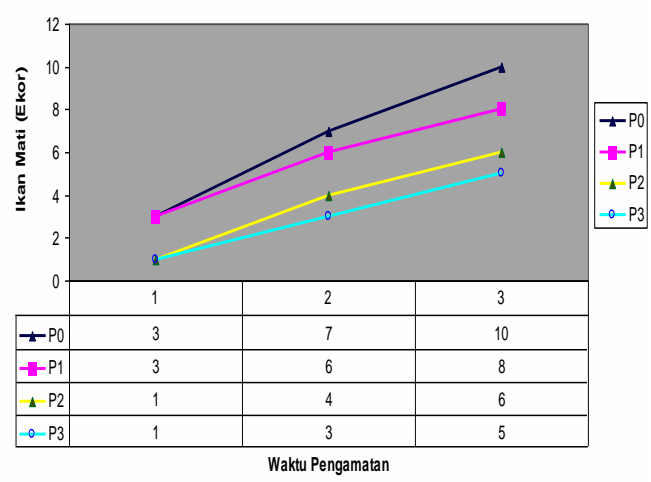

Gambar 6. Jumlah Ikan Mas Koki yang Mati Selama Penelitian

Berdasarkan gambar 6 di atas, dapat diketahui bahwa jumlah ikan mati pada perlakuan P0 selama 30 hari sebanyak 10 ekor, sedangkan pada perlakuan P1 sebanyak 8 ekor. Pada perlakuan P2 sebanyak 6 ekor, sedangkan pada perlakuan P3 jumlah ikan yang mati sebanyak 5 ekor. Berdasarkan keterangan tersebut dapat diketahui bahwa jumlah ikan mati yang terendah terdapat pada perlakuan P3 dengan pemberian tepung Cacing Darah 75\% pada pakan pellet $25 \%$. Berdasarkan perhitungan analisis statistik kelangsungan hidup Ikan Mas Koki (Carassius auratus) diperoleh hasil analisis sidik ragam kelangsungan hidup ikan selama penelitian dapat dilihat pada Tabel 7 perlakuan P0 hingga P3 menjadikan kelangsungan hidup yang sama. Namun, hasil pengamatan menunjukkan bahwa perlakukan P3 dengan pemberian tepung Cacing Darah $75 \%$ pada pakan pellet $25 \%$ merupakan perlakuan yang tertinggi.

Selain pakan, kelangsungan hidup ikan juga dapat dipengaruhi oleh faktor lain seperti oksigen terlarut. Berdasarkan hasil pengamatan, diperoleh bahwa oksigen terlarut berkisar yang 
terendah $2 \mathrm{mg} / \mathrm{l}$ dan yang tertinggi $3 \mathrm{mg} / \mathrm{l}$. Hal ini sesuai menurut Rahmi et al (2012) menjelaskan bahwa Ikan Mas Koki dapat bertahan pada tingkat oksigen terlarut kisaran 4 $\mathrm{mg} / \mathrm{l}$.

\section{KUALITAS AIR}

Kondisi kualitas air selama penelitian berlangsung masih dapat ditoleransi oleh Ikan Mas Koki (Carassius auratus) dengan penambahan tepung Cacing Darah pada pakan. Pengamatan kualitas air selama penelitian disajikan pada Tabel 8

Tabel 8. Hasil Pengamatan Kualitas Air selama Penelitian

\begin{tabular}{lcccc}
\hline \multirow{1}{*}{ Parameter } & Satuan & \multicolumn{2}{c}{ Rata-rata } & \multirow{2}{*}{ SNI 06-6989.23-2005 } \\
\cline { 3 - 4 } & & Terendah & Tertinggi & \\
\hline Suhu air & ${ }^{0} \mathrm{C}$ & 27 & 28,7 & \\
Oksigen terlarut & $\mathrm{mg} / \mathrm{l}$ & 2,00 & 3,00 & Kisaran $27 \pm 28{ }^{\circ} \mathrm{C}$ \\
pH & $\mathrm{Unit}$ & 7 & 8,1 & Minimun 4 \\
Amonia $\left(\mathrm{NH}_{3}\right)$ & $\mathrm{mg} / \mathrm{l}$ & 0,10 & 0,25 & $6,5-8,5$ \\
\hline
\end{tabular}

Sumber : Pengolahan Data Sekunder

Kualitas air selama penelitian dapat dijelaskan sebagai berikut.

\section{Suhu}

Berdasarkan hasil pengamatan, diperoleh bahwa selama penelitian suhu air terendah $27^{\circ} \mathrm{C}$ dan tertinggi $28,7^{\circ} \mathrm{C}$. Hal ini senada penjelasan Perakasa (2003) yang menyatakan bahwa suhu air yang ideal pada Ikan Mas Koki berkisar antara $27^{\circ} \mathrm{C}$ hingga $28^{\circ} \mathrm{C}$.

2. $\mathrm{pH}$

Berdasarkan hasil pengamatan, diperoleh bahwa $\mathrm{pH}$ air selama penelitian berkisaran antara 7 hingga 8,1. Menurut Rahmi et al (2012) menjelaskan bahwa $\mathrm{pH}$ yang baik untuk Ikan Mas Koki berkisar 6.5 - 8.5.

3. Oksigen terlarut

Berdasarkan hasil pengamatan, diperoleh bahwa oksigen terlarut berkisaran yang terendah $2 \mathrm{mg} / \mathrm{l}$ dan yang tertinggi $3 \mathrm{mg} / \mathrm{l}$. Menurut Syaifudin et al (2004) menjelaskan bahwa Ikan Mas Koki dapat bertahan pada tingkat oksigen terlarut kisaran $4 \mathrm{mg} / \mathrm{l}$.

4. Kadar Amonia $\left(\mathrm{NH}_{3}\right)$

Kadar Amonia $\left(\mathrm{NH}_{3}\right)$ dari data pengamatan rata-rata terendah $0,10 \mathrm{mg} / \mathrm{l}$ dan yang tertinggi $0,25 \mathrm{mg} / \mathrm{l}$. Menurut Syaifudin et al (2004) bahwa kadar maksimum kandungan Amonia $\left(\mathrm{NH}_{3}\right)$ sebesar $1,5 \mathrm{mg} / \mathrm{l}$. Dengan demikan, bahwa kisaran amonia dalam penelitian ini masih dapat digunakan untuk kelangsungan hidup Ikan Mas Koki.

\section{KESIMPULAN DAN SARAN}

\section{Kesimpulan}

Berdasarkan hasil penelitian yang telah dikemukakan sebelumnya dapat disimpulkan sebagai berikut.

a. Pertambahan berat Ikan Mas Koki (Carrassius auratus) tertinggi terletak pada perlakuan P2 (pemberian tepung Cacing Darah 50\% pada pakan pellet 50\%) dengan laju pertambahan berat harian sebesar 0,023 gram/hari, sedangkan pertambahan panjang Ikan Mas Koki (Carrassius auratus) tertinggi terletak pada perlakuan P3 (pemberian tepung Cacing Darah $75 \%$ pada pakan pellet $25 \%$ ) dengan lajur pertambahan panjang harian sebesar $0,032 \mathrm{~cm} /$ hari.

b. Kelangsungan hidup Ikan Mas Koki (Carrassius auratus) tertinggi terletak pada perlakuan P3 (pemberian tepung Cacing Darah $75 \%$ pada pakan pellet $25 \%$ ) dengan rata-rata persentase sebesar $83,33 \%$.

2. Saran

Saran yang ingin disampaikan adalah penelitian ini hendaknya dapat dijadikan sebagai salah satu alternatif untuk budidaya Ikan Mas Koki (Carassius auratus) dengan pemberian kadar Cacing Darah yang sesuai sehingga mendapatkan hasil yang lebih sempurna.

\section{DAFTAR PUSTAKA}

Aggraeni, N.M. dan Abdulgani, N. 2013. Pengaruh Pemberian Pakan Alami dan Pakan Buatan Terhadap Pertumbuhan Ikan Betutu (Oxyeleotris marmorata) pada Skala Laboratorium. Jurnal Vol 2, No 2 (2013). Institut Teknologi Sepuluh Nopember.

Arief, M. 2009. Pengaruh Pemberian Pakan Alami Dan Pakan Buatan Terhadap Pertumbuhan Benih Ikan Betutu (Oxyeleotris marmorata Bleeker). Jurnal Ilmiah Perikanan dan Kelautan Vol. 1 No. 1. Fakultas Perikanan dan Kelautan Universitas Airlangga

Effendie, M. I. 1997. Biologi Perikanan. Pustaka Nusantara. Bogor.

Effendie, M. I. 2002. Biologi Perikanan. Yogyakarta : Yayasan Pustaka Nusantara. 163 hal.

Fujaya, Y. 2004. Fisiologis Ikan : Dasar Pengembangan Teknik Perikanan. Rineka Cipta. Jakarta. 
Gustiano, Rudhy. 2014. Survai Potensi, Distribusi Sumber Daya, Dan Usaha Ikan Hias Air Tawar Di Beberapa Sentra Produksi. Media Akuakultur Volume 3 Nomor 1 Tahun 2008.

Hanafiah, K. A. 2011. Rancangan Percobaan : Teori dan Aplikasi. Fakultas Pertanian. Universitas Sriwijaya. Raja Grafindo Persada. Jakarta.

Khairuman dan Amri, K. 2013. Membuat Pakan Ikan Konsumsi. Agromedia Pustaka. Jakarta. Halaman 17.

Parlinggoman, D. Shafruddin, dan Sumantadinata, K. 2007. Pertambahan dan Produksi Larva Cacing Darah Chironomus sp. pada Media Yang Dipupuk Kotoran Ayam Dosis 1,0-2,5 Gram/Liter. Departemen Budidaya Perairan, Fakultas Perikanan dan Ilmu Kelautan, Institut Pertanian Bogor, Kampus Darmaga, Bogor.

Perakasa. B. 2003. Permasalahan Mas koki dan Solusinya. Penebar Swadaya. Jakarta.

Rahmi, A, Muslim dan Zuhriyani, H 2012. Pemeliharaan Ikan maskoki (Carassius auratus) Dengan Pemberian Pakan Yang Berbeda. Jurnal Fisheries 1(1) : 1-10
Sunarto. 2009. Pemberian Pakan Buatan Dengan Dosis Berbeda Terhadap Pertumbuhan Dan Konsumsi Pakan Benih Ikan Semah (Tor douronensis) Dalam Upaya Domestikasi. Jurnal Akuakultur Indonesia, 8(1): 67-76 (2009). Fakultas Perikanan dan Ilmu Kelautan Universitas Muhammadiyah Pontianak

Syaifudin, M. Carman, O. dan Sumantadinata, K. 2004. Keragaman Tipe Sirip pada Keturunan Ikan Maskoki Strain Lionhead (Carassius aurstus). Jurnal Akuakultur Indonesia. Institut Pertanian Bogor. 3(3) : 1-4

Widanarni, D.D. Mailanadan O. Carman. 2006. Pengaruh Media yang Berbeda terhadap Kelangsungan Hidup dan Pertambahan Larva Chironomus sp. Departemen Budidaya Perairan, Fakultas Perikanan dan Ilmu Kelautan, Institut Pertanian Bogor, Kampus Darmaga, Bogor

Yusuf, R.W.N. 2009. Isolasi dan Identifikasi Bakteri Gram Negatif Pada Luka Ikan Maskoki (Carassius auratus) Akibat Infestasi Ektoparasit Argulus sp. Fakultas Perikanan dan Kelautan Universitas Airlangga Surabaya. 